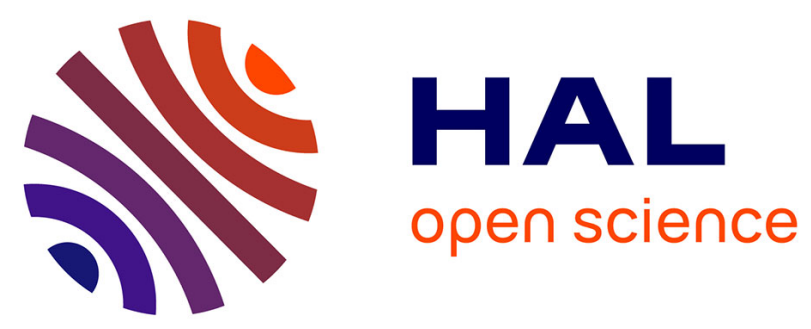

\title{
Maintaining an Institution: The Institutional Work of Michelin in Haute Cuisine around the World
}

\author{
Isabelle Bouty, Marie-Léandre Gomez, Carole Drucker-Godard
}

\section{To cite this version:}

Isabelle Bouty, Marie-Léandre Gomez, Carole Drucker-Godard. Maintaining an Institution: The Institutional Work of Michelin in Haute Cuisine around the World. 2013. hal-00782455

\section{HAL Id: hal-00782455 \\ https://essec.hal.science/hal-00782455}

Preprint submitted on 1 Feb 2013

HAL is a multi-disciplinary open access archive for the deposit and dissemination of scientific research documents, whether they are published or not. The documents may come from teaching and research institutions in France or abroad, or from public or private research centers.
L'archive ouverte pluridisciplinaire HAL, est destinée au dépôt et à la diffusion de documents scientifiques de niveau recherche, publiés ou non, émanant des établissements d'enseignement et de recherche français ou étrangers, des laboratoires publics ou privés. 


\title{
Maintaining an Institution: The Institutional Work of Michelin in Haute Cuisine around the World
}

\author{
Research Center \\ ESSEC Working Paper 1302
}

2013

Isabelle Bouty

Marie-Léandre Gomez

Carole Drucker-Godard 
Bouty, Gomez, \& Godard - Michelin around the world

\title{
Maintaining an institution: \\ the institutional work of Michelin in haute cuisine around the world
}

\author{
Isabelle Bouty, Université Paris Ouest, ibouty@u-paris10.fr \\ Marie-Léandre Gomez, ESSEC Business School, gomez@essec.fr \\ Carole Drucker-Godard, Université Paris Ouest, carole.godard@u-paris10.fr
}

We draw on an analysis of the Michelin red guide's strategy in haute cuisine around the world to develop a better understanding of institutional maintenance work by dominant organizations and more specifically by legitimating organizations. Institutional-based approaches postulate that organizations are constrained and shaped by a field-level framework of values, norms, and expectations. Within this view, institutional theorists have investigated various phenomena such as the diffusion of standards and structures that are considered legitimate within a field, or their constraining influence over individual organizations. More recently some scholars drew attention towards the notion of institutional work (Lawrence and Suddaby, 2006; Lawrence, Suddaby and Leca, 2009) in order to better take interactions between actors' agency and institutions into consideration. Institutional work "describes the practices of individual and collective actors aimed at creating, maintaining, and disrupting institutions" (Lawrence et al., 2011: 52). It relates institutions and actions.

Among the three generic types of institutional work, the question of how institutions are maintained over time is a line of inquiry that has attracted relatively less attention than others so far (Scott, 2001); institutional scholars often tended to take perpetuation for granted. It is a definitely central question however. As Lawrence and Suddaby (2006: 227) insist, "although institutions are associated with automatic mechanisms of social control that lead to institutions being relatively self-reproducing [...] relatively few institutions have such powerful reproductive mechanisms that no ongoing maintenance is necessary". A large amount of institutional work is required to maintain institutions, that is, to support, repair, or even recreate them. As Lawrence \& Suddaby (2006: 232) and Quinn-Trank \& Washington (2009: 239, 256) further note, maintaining institutions does not merely consists in preserving stability and guarding against change, especially because persistence is to be achieved in the context of evolving environments. As such institutional work aimed at maintaining institutions require efforts and may involve repetition as well as changes. It is however very different from institutional entrepreneurship (Quinn-Trank \& Washington, 2009: 256). It regards working towards endogenous evolutions of existing fields and is aimed at preserving 
Bouty, Gomez, \& Godard - Michelin around the world

institutions by developing and policing the normative, cognitive and regulative arrangements that underpin them, as opposed to the most often exogenous triggered changes aimed at disrupting these institutional arrangements that are central to institutional entrepreneurship.

There is a wide variety of actors likely to work towards maintaining institutions. However those actors whose occupation is to award legitimacy to others certainly hold a specific place in regard of institution maintenance. Because there are those who attest that other actors do (or don't) meet certain standards, legitimating organizations personify and enforce the normative, cognitive and regulative arrangements that underpin institutions: they are both a vehicle and a symbol of institutional processes. As such, these particular organizations exert power over the field as dominant actors as long as they and institutions are somehow maintained in accordance. Maintenance work is therefore vital to legitimating organizations. Yet and further, all these legitimating organizations are not in similar position in this regard. As Durand and McGuire (2005) note, legitimating organizations may be either internal (when they are established as a result of actors in a domain organizing themselves for peer-based accreditation such as is the case for professional associations or the AACSB [Durand \& McGuire, 2005; Greenwood et al., 2002]) or external (when the organization granting legitimacy and accreditation is external to the organizations seeking it, as is for example the case of ISO or of credit rating agencies [Guler et al., 2002; White, 2010]). Our study investigates the second type of situation. In this case, the legitimating organization does not result from internal field organizing and consensus. The criteria, rules and norms that base accreditation are therefore de facto placed upon organizations in the field without them being able to exert direct influence on their definition and evolution. This characteristic is of particular importance in terms of field maintenance for two reasons. First, as a field grows institutionalized the criteria, norms and rules that base accreditation and legitimacy evolve according to the legitimating organization's understanding, position, objectives and strategy, not over a field-level consensus or debate (as opposed to what happens in peerbased evaluation). Second, and in consequence, the position of the legitimating organization in the field and institutional maintenance grow mutually dependant. The legitimating organization's position is based on certain normative, cognitive and regulative arrangements that, among other things, include acknowledgement of its role and legitimacy. The legitimating organization therefore is willing to preserve the ongoing institutional arrangements. Work to maintain institutions and the legitimating organization strategy are therefore convergent yet potentially loosely coupled to other actors in the field.

Given the extent to which contemporary organizational fields are dominated by such legitimating non-peer-based organizations (especially but not only in the medical care, education, finance and banking sectors) it is highly surprising that this situation has not received much attention so far. To our knowledge studies that investigated the maintenance 
Bouty, Gomez, \& Godard - Michelin around the world

of institutions by legitimating organizations most often focused on peer-based organizations. In order to contribute filling this research gap, we investigate the following research question: how does a dominant non-peer-based legitimating organization work towards institutional maintenance to secure its position in a field? We investigate this question based on the case of the Michelin red guide in gastronomical haute cuisine and its internationalization strategy. We show that going international the Michelin red guide worked towards both maintaining haute cuisine as an institution and its own position as the dominant legitimating organization in the field. In particular we highlight that Michelin combined different types of institutional work in geographic expansion, especially policing, valorizing and embedding that at the same time as it further assed its dominant position. In the following pages, we first outline past results on institution maintenance and legitimating organizations. Second, we turn to our empirical study to describe haute cuisine as an institutional field, our methods, data and analysis.

\section{MAINTAINING INSTITUTIONS AND LEGITIMATING ORGANIZATIONS}

Institutions, defined as observable and collective forms patterning social practices underpinned by norms (Czarniawska, 1997), are "malleable yet firm, somewhat illusory yet recognizable, and fleeting as well as permanent" (Dacin et al., 2010: 1394). The permanence of institutions has often been taken for granted in literature especially because of the social control mechanisms they comprise and that were considered the source of institutions' selfreproduction. Such a black box is "somehow ironic" as Quinn-Trank \& Washington (2009: 235) put it, especially as one of the major features of institutions is their relative durability. However, "relatively few institutions have such powerful reproductive mechanisms that no ongoing maintenance is necessary" (Lawrence \& Suddaby, 2006: 227). On this base, institutional work aimed at maintaining institutions appeared a topic central to institutional approaches and some scholars engaged in developing empirical studies to highlight the various aspects of such maintenance work in institutions. In an initial mapping of the topic, Lawrence \& Suddaby (2006: 230) outlined the reduced number of studies investigating maintenance in the past and grouped former results into six categories along a continuum of "comprehensibility" (2006: 237). At the comprehensible end of the spectrum are three kinds of work aimed at setting and maintaining rules: enabling, policing and deterring. Enabling is the work of setting rules; it involves the creation of standards but also of certain roles such as regulatory agencies, authorization agents, or professional associations. Policing is the work aimed at enforcing these rules in order to ensure compliance; it involves sanctioning and inducing, and ranges from enforcement to auditing and monitoring. Last, deterring deals with work aimed at dissuading change, with "the threat of coercion to inculcate the conscious obedience of institutional actors." (Lawrence \& Suddaby, 2006: 232). Around the other end of 
Bouty, Gomez, \& Godard - Michelin around the world

the comprehensibility continuum institutional work aimed at maintaining the reproduction of norms and beliefs systems are to be found: valorizing/ demonizing, mythologizing and embedding/ routinizing. Valorizing (and its counterpart, demonizing) is aimed at valuing and illustrating the norms underpinning the institution through the making of highly positive (or negative) demonstrative examples. Though close, mythologizing is different and rather relates to the preservation of the norms building on histories and legends dawn from the institution's past in order to provide constituents with an understanding of why norms are pivotal. Last, embedding is the work of infusing constituents' practices with the underpinning institutional norms so that the institution is preserved and reproduced in constituents' routines.

As a burgeoning field of investigation, institutional maintenance has been the focus of only a few empirical studies so far. These were carried out in one or another of the six directions mapped out by Lawrence \& Suddaby (2006). The academic world has been used as a favorite field of investigation, especially because of enduring accreditation systems and clearly identifiable actors (such as the AACSB or universities). In their 2005 study Durand \& McGuire highlight domain expansion as type of maintenance work. Domain expansion is more precisely a form of enabling work: it consists in setting and adjusting membership rules. As the authors further stress, this form of maintenance work is of growing importance today as many fields (from academia to health and finance) become globalized. Investigating the AACSB too, yet under a different light, Quinn-Trank and Washington (2009) further described another type of enabling work of the AACSB that accompanied its revising membership rules: the AACSB also revised its accreditation rules in the years 1990's. Quinn-Trank and Washington (2009) specifically show that expanded membership and a new mission-based system were adopted and promoted by the AACSB in conjunction. In the terms of Zietsma \& Lawrence (2010), the AACSB thus carried out boundary and practice work. This enabling work allowed the AACSB to maintain accreditation as an institution in face of the growing power of media to define what quality was. These two studies on the AACSB also illustrate that maintenance work may involve bringing changes to institutional arrangements in relation to actors' strategy. Another study in the academic world, by Dacin and colleagues (2010), investigates a more micro level of analysis, and examines the role of rituals of formal dining at Cambridge. It contributes to provide a better understanding of how institutions are embedded within constituents (embedding / routinizing work). Dacin and colleagues point out the importance of rituals as micro enactments supporting macro institutional maintenance. Rituals in particular drive to the progressive transformation of participant's identities and perceptions of self. They therefore have, authors point out, trans-temporal and spatial effects and contribute to maintaining institutions at a macro level (maintaining class-stratification throughout British society in the case of formal dining). With the case of European 
Bouty, Gomez, \& Godard - Michelin around the world

management education, Wedlin (2010) further points out the self-reinforcing nature of such maintenance work.

Because their occupation is to award legitimacy to others, legitimating organizations are important actors in regard of field maintenance. As soon as they are not state related (that is granted with legal mandate; Hoffman, 1999) legitimating organizations are in fact directly interested in actively working towards field maintenance: their role and legitimacy rest on acceptance by fields constituent of both the legitimating organization and of the standards it vehicles. This acceptance stems from normative and cognitive arrangements underpinning the institution (Scott, 1991; Townley, 2002) that are therefore to be maintained (from the legitimating organization's standpoint). Studies of the AACSB's strategy to defend its ability to deliver accreditation in the years 1990's provide a compelling illustration of this issue (Durand \& McGuire, 2005; Quinn-Trank \& Washington, 2009).

To perform such maintenance work, legitimating organizations use powerful tools: accreditation, rankings, and ratings. These are based on commensuration, or the transformation of qualities into quantities with the view to develop common metrics for disparate units (Espeland \& Stevens, 1998: 316). Commensuration both unifies and distinguishes objects (Espeland \& Sauder, 2007). It unifies "objects because all entities measured bear a common relationship to each other derived from their shared metric [which makes] the forms of heterogeneity that exist among them less visible " (Espeland \& Sauder, 2007: 19). It distinguishes objects because it also creates unavoidable comparison relationships between them. Rankings and ratings are therefore "a powerful engine for producing and reproducing hierarchy since they encourage the meticulous tracking of small differences" (Espeland \& Sauder, 2007: 20). Commensuration by legitimating organizations is further based on the encoding of certain norms and assumptions; ratings, rankings and accreditations vehicle a certain understanding of what is considered good (or not) within the field. Several authors showed how these categorization, accreditation, ranking and rating tools sustained reproduction in a field (for example Espeland \& Sauder, 2007; Lounsbury \& Rao 2004; or Wedlin, 2010). As Espeland \& Stevens (1998), Lounbury \& Rao (2004), or more recently Huault \& Raynelli-Weiss (2011) further suggest, these operations are highly politic driven.

This last point is of major importance as, as Durand \& McGuire (2005) point out, there are in fact two very different types of non-state-related legitimating organizations. The first type is peer-based organizations. These are organizations established as a result of actors in a domain organizing themselves: for example professional associations or academic agencies. Greenwood \& Suddaby (2002) show that professional associations are important regulatory agents. They detail the role of these associations in times of institutional evolutions an especially highlight their impact on theorization of practices as they enable the 
Bouty, Gomez, \& Godard - Michelin around the world

production and reproduction of shared meanings and understandings. Professional associations are arenas of interaction between field's constituents. As such they are places where shared understandings and norms can develop. They are also are consensually accepted actors whose role is to monitor compliance and reproduction of norms. These shared norms, typifications and the accreditation or ranking systems that accompany them in turn provide justifications for actors' positions in the field and influence their understanding of legitimacy (Wedlin, 2010).

The second type of legitimating organizations is non-peer based. In this case the organization granting legitimacy is external to the organizations seeking it. This is for example the case of ISO (Guler et al., 2002), of credit rating agencies (Dejan et al, 2004; White, 2010) or of such guidebooks as the Parker guides (wine) or Michelin red guide (restaurants). Of course, as Dejan et al (2004) illustrate, measurement tools can be initially developed on the base of the main field stakeholder's cognitive framework. However, this correspondence may not be maintained over time and measurement tools can grow to carry different stakes. For example, Karpik (2000) shows how the Michelin guide progressively transformed its system when it evolved from a technical to a tourist and then a gastronomic guide; with such evolution its impact on restaurants grew stronger without the restaurants being involved in the process. Ruef \& Patterson (2009), retracing the emergence of one of the first general systems of business rating and classification in the US, analyze how the classification and rating system developed by Dun and its agents impacted firms. They especially highlight the relationship between classification and rating. The later, initially intended at providing information to non local actors (correspondence between the tool and stakeholders), turned out to also be a coercive means to enforce Dun's classification. White (2010) further develops a similar argument as he retraces history in order to understand the role played by rating agencies in the recent financial crisis.

Given these accounts the reduced number of studies investigating the strategy and maintenance work of legitimating organizations is highly surprising. In particular there exists to our knowledge no study focusing on the strategy of non-peer-based legitimating organizations in the perspective of field maintenance. These organizations are most of the time conceived as transparent information providers the strategy of which is never accounted for. However the topic is of importance. As many authors note, contemporary organizational fields are growingly dominated by proliferating standard-setting agencies of different kinds. These agencies are powerful institutional players interested in field maintenance because their position depends on such maintenance. As such their strategy is likely to impact entire fields through the institutional arrangements they symbolize, vehicle and defend. In order to contribute to filling this gap, we investigate the internationalization of the Michelin red guide in haute cuisine and analyze it as institutional maintenance work. 
Bouty, Gomez, \& Godard - Michelin around the world

\section{RESEARCH CONTEXT}

We base our empirical study on the Michelin red guide and its internationalization strategy, which we analyze as institutional maintenance work aimed at defending its position in haute cuisine worldwide and, in relation, a particular understanding of what haute cuisine (gastronomy) is and should be.

Contemporary haute cuisine is a highly institutionalized field (Fauchart \& Von Hippel, 2008; Rao et al., 2003, Gomez \& Bouty, 2011). And Michelin has been the uncontested (though not always unchallenged) arbiter of the field in Europe for several decades (Karpik, 2000, 2010; Lane, 2010; Rao et al., 2003). At the end of the twentieth century, it was covering more than 15 European countries with an identical rating system of restaurants.

Insert Table 1 about here

In the years 2000's Michelin further expanded outside Europe to America and Asia, with red guides dedicated to the United-States (New-York in 2005, followed by Chicago, San Francisco, and Las Vegas), Japan (Tokyo Yokohama Kamakura in 2007, followed by Kyoto Osaka) and other Asian cities (Hong Kong and Macau). We will primarily focus our study on Michelin's expansion to New-York and Tokyo.

Scholars documented the French roots of contemporary haute cuisine and agree to situate its birth around the French revolution and the political, economic and cultural upheavals it produced (for example Ory, 1998; Parkhurst-Ferguson, 1998, 2004). In particular, the post-revolutionary emergence of the restaurant as a specific cultural site for sophisticated dinning for the bourgeoisie accompanied that of gastronomic discourse, and gastronomy emerged as a cultural field with norms and rules developed in treatises and other forms of textual productions. Yet, as Parkhurst-Ferguson (2004) and Karpik (2000; 2010) account, it is the Michelin red guide which really made restaurants' rating "the national affair that it remains today and the international affair that the annual publication has become" (Parkhurst-Ferguson, 2004: 158).

The Michelin red guide's system to evaluate and classify restaurants developed along the twentieth century through different phases. As Karpik (2000) analyses, the Michelin guide was initially of technical intent (1900-1908). Then it became a tourist guide (1909-1933) before turning into its present form of purely gastronomical guide (from 1934) with a stabilized system of restaurant's evaluation. The Michelin rating system is organized around two operations that in the end permit comparison between restaurants: inclusion/exclusion, and ranking (Karpik, 2010). First the guide includes only certain restaurants and therefore excludes others. Only a small share of the restaurants that are evaluated by Michelin is actually included in the guide (one tenth in France for example). As such inclusion itself is foundational as an acknowledgement of minimum gastronomic quality (based on yet 
Bouty, Gomez, \& Godard - Michelin around the world

unformulated standards). Among the restaurants included in the guide, comparison is then made possible through ranking along a variety of dimensions, especially cuisine and comfort, with a variety of pictograms. Among these, Michelin stars are today the ranking dimension most valued in the field. Stars are used to rank restaurants according to the cuisine that they serve. At stake are the quality of the products, cooking's regularity, technical mastery and the chef's creativity (interview at Michelin). This ranking ranges from no star (for a majority of restaurants) to three stars (for an elite minority; for example in France three-star restaurants amount to usually only $5 \%$ of the 400 to 600 restaurants in the guide). A one-star ranking reflects very good cooking, a two-star ranking means a restaurant worth a detour, and a three-star ranking means exceptional cuisine worth a special journey. Comfort is represented by forks and restaurants are ranked from non to five forks. In addition to this information, Michelin provides a short qualitative description (2 lines) sustained by the mention of up to three signature dishes for each restaurant. An important underlying assumption of the Michelin system is the difference between food and comfort. This difference is all the more important as stars grew in importance over the years and are today the criteria most valued by both consumers (customers) and producers (restaurants and chefs) in haute cuisine (Karpik, 2000; Parkhurst-Ferguson, 1998; Rao et al., 2003; Svejenova et al., 2007).

Michelin's methodology is organized around four building blocks that are regularly claimed by Michelin and media at large. The first one is independency; the red guide is funded solely by the Michelin Corporation and does not draw its resources from selling advertising space. The guide contains no commercials. The second building block is constituted by the famous Michelin's inspectors. The inspectors are the Michelin employees who visit and evaluate the restaurants. They are regular Michelin employees trained in the hotel and catering industry, who work anonymously and pay for their meals in the restaurants they visit. Third is the number of visits. Michelin inspectors visit many restaurants, more than those which are finally included in the guide (this bases the inclusion / exclusion principle). In addition before being ranked with stars in the guide, a restaurant is visited several times (presumably up to 10 times for three-star restaurants). Last but not least is secrecy. Michelin is very secretive on its methods and functioning (no wonder given the anonymousness of inspectors), especially on how visit accounts are consolidated into decisions of inclusion and ranking.

In part because of its being so secretive, Michelin has been and still is under regular attack by various constituents of the European field, from chefs to other guidebooks, food critics, or even former inspectors. It would have even been surprising indeed that Michelin's hegemony over haute cuisine came without controversy. For example the GaultMillau guide took opportunity of the nouvelle cuisine wave to question Michelin's authority on the base of both gastronomic and political grounds (Ory, 1998; Rao et al., 2003). Another illustration is 
Bouty, Gomez, \& Godard - Michelin around the world

the extent to which in France for example, nearly each annual issue of the guide comes with its habitual media-conveyed lot of disagreement on ranking and the number of stars attributed to one or another restaurant or even sometimes on Michelin's method. The dispute is even stronger when a formerly three-star restaurant is demoted to two stars (which is regularly the case) and a debate develops on the topic of whether this decision is pertinent or not. However throughout time, Michelin successfully defended its dominant position and is today still the acknowledged authority of European haute cuisine. Each issue of the guide is expected, analyzed, discussed, and in the end used as a reference by all actors, from customers to chefs, other stakeholders, and even critics, who take the guide's ranking as a reference would they agree with it or not. That the Michelin red guide is an annual topic in Europe even testifies of its institutional dominance over contemporary haute cuisine, and the matter of Michelin's detractors' arguments being "true" or "false" is in fact of little to no consequence as long as Michelin's rating system is the rule as has been the case so far in European countries.

In the twenty first century, however, gastronomy undergoes a new evolution as the field becomes international (Ferguson, 2004: 168; Svejenova et al., 2007). Chefs travel around the world, as do their clients, rendering haute cuisine international and more competitive. Elite chefs also develop multiple restaurants in different countries, as is for example the case of Alain Ducasse (who runs restaurants in the UK, the US, Hong Kong, Switzerland, Italy, Libanon...), or Pierre Gagnaire (who lately opened in London, Tokyo, Hong-Kong, Dubai, Las-Vegas Moscow, and Berlin). In this context Michelin again has to defend its position under several aspects: haute cuisine spans new geographic spaces which it does not cover; new trends such as fooding emerge, new and more democratic guides develop such as the Zagat or Tripadvisor (Jeacle \& Carter, 2011)... Altogether the current evolutions in international haute cuisine represent challenges to Michelin's authority but are also opportunities to further defend it through institutional maintenance work.

\section{METHOD}

In order to analyze the Michelin red guide's internationalization as maintenance work in the field of gastronomical haute cuisine, we focused our attention on its expansion to NewYork and Tokyo. We especially retraced the expansion process paying attention to both Michelin's actions and to how its rating local restaurants was progressively taken for granted (or not) by local actors. For this purpose we collected data from two sources.

First we collected data directly from Michelin, in the form of the New-York and Tokyo red guides. Michelin also accepted that we interview its internationalization executive manager. This interview is of pivotal importance for our study given our institutional work theoretical orientation, because it provided us with firsthand Michelin information, quite a rare 
Bouty, Gomez, \& Godard - Michelin around the world

resource given Michelin's usual secrecy. The interview lasted two hours and followed a semidirective format. We were unfortunately unable to record it. Yet each of us paid attention to take detailed notes, which we consolidated afterwards. Of particular interest in the interview was the fact that Michelin's current internationalization executive manager (whom we interviewed) directly participated to the New-York guide's launching in 2005 and fully managed the guide's expansion to Japan in 2007 (Tokyo guide, at first). We therefore had primary accounts of Michelin's doings and organization in both cities. During the interview, we also dealt with such themes as the changes that Michelin brought to New-York and Tokyo restaurant's scenes, or the local reactions to Michelin's arrival. Second we needed to collect data reflecting how Michelin's expansion to New-York and Tokyo was received, in order to evaluate the resonance of Michelin and the extent to which expansion resulted into institutionally maintaining Michelin's dominant position over the growingly international haute cuisine field or not. For this purpose we extracted from the Factiva database all the local press articles (and only those) dealing with the Michelin red guide in New-York and Tokyo between the years 2000 and 2010. This resulted in a total of 169 articles. Articles in Japanese language were translated with the automatic translator integrated into Factiva.

We coded these articles with emergent first order categories on the basis of words and expressions used in the texts. Then, we regrouped these categories into second-order themes which we used both to structure our analysis and as dimensions which evolutions we traced in time. Last and in order to be able to follow the evolution of how Michelin was generally received, we grouped our second order themes into two general directions: positions favorable and unfavorable to Michelin's red guide. Table 2 presents our first order categories, second order themes, and general themes.

Insert Table 2 about here

\section{FINDINGS}

The launching of the Michelin red guide in New-York and Tokyo followed an identical process (interview). In both cities, the launching was pre-announced six months in advance (Daily Yomiuri, 03/19/2007; New York Times, 03/04/2005). Then, the local red guide was launched at a press conference. However, local conditions were significantly different in terms of food culture and market.

\section{Michelin in New York}

In New-York gastronomic columns in newspapers (such as in the New York Times) together with a widely distributed client-based local guide (Zagat) represented a form of gastronomic discourse, despite reduced culinary culture (no clear culinary configuration rather a form of culinary pluralism) and "a relative lack of cultural authority" (Parkhurst- 
Bouty, Gomez, \& Godard - Michelin around the world

Ferguson, 1998: 634). As Parkhurst-Ferguson further points out (2008), these existing productions were significantly different from what Michelin was about to bring to New-York. Gastronomic journalists and columnists judge restaurants according to their personal taste and criteria. Democratic guides such as the Zagat that are based on diners' opinion are a plebiscite (Parkhurst-Ferguson, 2008: 52). Michelin for its part is a "tribunal" (ParkhurstFerguson, 2008: 51), with standards exceeding personal opinion, especially because of the trained professional undercover inspectors. As such Michelin's arriving in New York represented a new form of legitimating process.

The guide's launching was pre-announced at the end for February 2005. At that moment it was made clear by Michelin that its undercover inspectors were already engaged in the process of visiting and evaluating the city restaurants. Nine months later, early November 2005, the New York red guide was launched and its restaurant ranking made public. It immediately created shockwaves in the local press as Figure 1 illustrates:

Insert Figure 1 about here

Early November 2005, the debates that were echoed in the press were partly based on positions taken by various actors against the red guide and its ratings. In particular the guide was perceived as too French and offering a ranking that was too different from that of Zagat (therefore from client's opinions) to be credible. For example: "The French-oriented guide - [...] has already raised the hackles of some chefs and restaurant critics who are sniffing that its awarding of stars went a bit heavy on the Gallic" (New York Daily News, 11/04/2005); or "The Grocery, didn't get a star [...] even though its current rating in the Zagat guide is a full point higher than Restaurant Saul. (New York Daily News, 11/03/2005). Michelin's ranking system was also pointed at as dubious: the inspectors' skill seem of little coherence with the New-York dining scene. For example: "Many wonder if the Michelin critics (who may as well be secret agents for all the mystery shrouding them) will be able to evaluate the more "laid-back" American dining scene objectively." (New York Daily News, 09/28/2005).

Besides those critics, the other of reactions remained general, mainly referring to the red guide's global notoriety. However, as early as November 2005, some chefs already pointed out the meaningfulness of the guide and its ranking in the profession: "Saul Bolton of Saul said the honor is special 'because Michelin is the preeminent validating barometer in the world" " (New York Daily News, 11/02/2005); "I apprenticed only in three-star restaurants when I was in France, and this means a lot to me, [Jean-Georges Vongerichten] said. 'It puts me on the level with my mentors" (New York Times, 11/02/2005).

Over the following years, the annual issue of the New York red guide has systematically been a topic in the press as autumn peaks in the number of press articles on 
Bouty, Gomez, \& Godard - Michelin around the world

Figure 1 testify. A closer look at the positions accounted for by the press however indicates and evolution in positions. As illustrated by Figure 2 the 2005 initial outcry transformed into overall more positive views of the red guide.

Insert Figure 2 about here

Figure 2 represents the evolution of the number of arguments favorable and unfavorable to Michelin that are reported in the press (therefore a total number superior to that of the number of articles). We used this count as a way to assess the vigor of the debate around the red guide and therefore the extent to which it gradually became taken for granted (or not) on the New-York scene. Figure 2 shows that the occurrence of arguments unfavorable to Michelin decreased in number when argument favorable to the red guide remained dominant, especially but not only at autumn peaks. Turning back to our first order categories and second order themes, we further analyzed the topics of these enduring arguments in more details. Our data indicate that the remaining oppositions centered on the perceived elitism of the New-York Michelin-starred restaurants, the price of which is often considered too high. On the other hand, looking in detail at more positive positions, we saw that Michelin's method quality arose as an important topic, with inspectors' competence and anonymousness, and the overall rigor of the rating process being put forward. For example: "Gavin Kaysen, the executive chef at Cafe Boulud, says [....] 'I respect their critics because they are professionals. ' Restaurants in the Michelin guide are rated by trained inspectors who guard their anonymity. The reviewers in New York are all Americans". (New York Times, 10/06/2010)

This last quote is also illustrative of another important theme in the enduring positions favorable to the red guide: the Michelin red guide in the eye of chefs themselves. As we already noted, the red guide was acknowledge as prominent by the chefs, from its launching in 2005. This theme persisted in the press articles, which constantly reported chefs' statements. Chefs who especially stressed the red guide's professional meaningfulness and the pride and happiness a star therefore represented to them. For example: "Eric Ripert, the chef and an owner of Le Bernardin, said he was beside himself when he learned of his ranking. [....] 'For us it's the grand slam' he added" (New York Times, 11/02/2005). In 2010 for example: " 'It's a big deal," Mr. Bastianich said. "It's about bragging rights. Michelin is becoming more recognized'. [...] 'I never complained,' Mr. Boulud said. 'I was patient. But I felt better when I finally got the third star. I always felt I deserved it as much as the others'." (New York Times, 10.06/2010)

The analysis of a last category of favorable arguments brought also noteworthy result: that which deals with the Michelin red guide's status. First of all, from 2007 on, local press articles growingly insist on the guide's status under several aspects, from its age to its 
Bouty, Gomez, \& Godard - Michelin around the world

international scope or its seriousness. This is especially visible in the way the guide is qualified. In 2005: "the French guide" (New York Times, 11/13//2005). Over the years, qualifications evolved to refer to prestige, respect and history. For example: "Michelin released its prestigious restaurant guide to New York City" (New York Daily News, 10/07/2008), "the highly respected international guide" (New York Daily News, 10/09/2007).

Second, the evolution of the share of press articles mentioning Michelin as a reference for gastronomy, either in general or in order to position the level of a particular restaurant significantly grew over the years as indicated on Figure 3.

Insert Figure 3 about here

Figure 3 represents the evolution of the share of articles in the local press which use Michelin's guide name as a reference to gastronomy or to the gastronomic level of a restaurant in such terms as for example: "The restaurant received a Michelin star in the 2009 guide book" (Wall Street Journal, 01/23/2009) or "they tested 68 servings [...] at 31 eateries ranging from the Michelin-starred Nobu to a corner convenience store" (Wall Street Journal, 12/04/2009). The evolution visible on Figure 3 is especially significant as it points to the way Michelin has been perceived through time. Before the launching of the New York red guide, Michelin was a name used as synonym of gastronomy. When the guide was announced suspicion developed (years 2004-2005) before the status of the guide was progressively restored over the following years.

Altogether, our analysis of the debate around Michelin's New York red guide, based on arguments and their evolution, points to the guide being growingly taken for granted on the local scene. As summarized by the New York Times: "Today, both guides [Zagat and Michelin] will announce their 2011 ratings in a changed environment: Michelin stars have become increasingly important, New York restaurateurs say, bringing significant business and prestige" (New York Times, 10/06/2010). Besides, and confirming this view, the debut edition of the Chicago red guide in 2010 benefited from a halo effect directly based on the guide's position in New York. The release was anxiously expected, and Michelin even had to move it up because an internet site had leaked information (interview). Also significant in regard of Michelin contemporary position is the way the New York press presented the event and local chefs reacted: "The decision by the century-old arbiter of exceptional cuisine to come here, of all places, shocked some who live far away and tend to think of this city's eating more in terms of broadening shoulders, hips and waists. " (New York Time, $11 / 17 / 2010$

\section{Michelin in Tokyo}

In Japan, the local context was quite different from what Michelin had experienced in 
Bouty, Gomez, \& Godard - Michelin around the world

New York, especially because culinary arts held central place in Japanese culture. The role of restaurants was also pivotal to society: meals are frequently eaten outside at restaurants. Some restaurants are not considered open public spaces yet rather elitist places where only those who know the address can be met. Last but not least and contrary to New York there barely existed any system for general restaurant's evaluation purpose in Tokyo. This was related to the Japanese culture in which third party judgment is hardly acceptable, and to the ways of Tokyoites who preferred exchanging confidential restaurants' addresses undercover and preserve their almost-non-public side (interview). The Japanese Ministry of Land, Infrastructure, Transport and Tourism (MLIT) had tried to set up such guide with the view to providing useful information to foreign tourist; but the project catalyzed the opposition of chefs and restaurants and was eventually abandoned (interview).

Despite the difference in local contexts, the red guide's debut in Tokyo was similar to that in New York two years earlier. On March 2007 Michelin pre-announced the launching and declared that its inspectors had already begun field work long ago. Nine months later, at the end of autumn 2007, the guide was released. As had been the case in New York the local press echoed the release, as illustrated by Figure 4.

Insert Figure 4 about here

Figure 4 displays the initial and recurrent annual autumn peaks in the number of local press articles dealing with the guide. A closer examination of the positions reported in articles shows that severe critiques were directed at Michelin. The guide was even "nicknamed the Red Ship, an allusion to the Black Ships that U.S. Commodore Matthew Perry sailed to Japan in the 1860s, bringing an end to the Japanese government's isolation policy" (Nikkei Weekly, 11/17/2008) Criticisms spanned a variety of themes yet were mainly focused on the ability of Michelin's inspectors to evaluate Japanese cuisine and in relation on the guide's style. For example: "The guide focused on Japanese cuisine for about 60 percent of the guide, causing traditionalists in Japan to question the ability of French tasters to distinguish the subtleties of special Japanese flavors" (The Japan Times, 12/16/2007); "Indeed, there is persistent skepticism about whether Michelin's evaluation expertise, developed in the Western culinary tradition, is really useful for rating Japanese restaurants ". (Nikkei Report, 12/15/2007). Over the following years, this line of argument dissolved as Michelin regularly claimed to have a growingly local team (therefore relevant skills). In the meantime, positions favorable to Michelin were for their part more stable and therefore became rapidly dominant as illustrated on Figure 5.

Insert Figure 5 about here

Figure 5 displays the growing relative importance of favorable arguments as criticisms 
Bouty, Gomez, \& Godard - Michelin around the world

against Michelin decline. Turning back to our second order themes and first order categories in order to analyze favorable arguments in more details, we observed that two themes were most represented:

- The Michelin red guide status: especially in regard of its international scope (for instance "the world-famous gourmet guidebook" (Nikkei Weekly, 11/30/2009), its sales (for example: "the prospective bestseller" (Nikkei Weekly, 11/17/2008), and the benefits of a Michelin ranking: "Most of the restaurants receiving good ratings now have waiting lists longer than the Krispy Kreme Doughnuts lines" (The Japan Times, 12/16/2007).

- $\quad$ The quality of the Michelin method: "high standards and impeccable integrity" (The Japan Times, 12/16/2008), "seven undercover restaurant evaluators used this time round were all Japanese [...] all of whom are employees of Michelin's local affiliates and have experience of working at hotels or restaurants" (Daily Yomiuri, 11/28/2009).

It is additionally noteworthy that if arguments about the guide's status are present as early as 2007, those dealing with the method quality really develop from 2009 as is exemplified by the descriptions of Michelin's inspectors' selection, training and rating criteria provided by some articles (for example Daily Yomiuri, 11/28/2009). These evolutions indicate a local growing acceptation of the Michelin red guide and its ranking. Besides, whereas in 2007 more than half of the articles didn't mention the guide as a reference and rather focused on the controversies it created, from 2008 on the guide is presented as an essential piece, for example: "The Japanese-language Michelin Guide Tokyo 2009 is due to hit shelves next Friday, and many local gourmets already have their copies reserved. [...] In fact, most of the eateries rated highly by Michelin are still enjoying brisk foot traffic despite spreading pessimism over the economy, according to restaurant industry insiders." (Nikkei Report, 11/14/2008).

Reinforcing this argument, our data indicate that the share of press articles mentioning Michelin as a reference for gastronomy, either in general or in order to position the level of a particular restaurant grew over the years as indicated on Figure 6.

Insert Figure 6 about here

Figure 6 shows that prior to the launching of the Tokyo edition, Michelin was used as synonym of gastronomy. This used has been strongly questioned in 2007 as controversies on the Tokyo edition grew. Yet the red guide was rapidly restored as a reference afterward. Last, our data indicate that the 2010 slight drop corresponds to Michelin announcing the upcoming release of the Kyoto guide; on this occasion, further controversies developed in Kyoto that were reported in the press at the same time as Tokyoite actors continued to use Michelin as a reference. It is perceptible in the press and our interview at Michelin confirmed that Kyoto constituted a difficult context for the guide, especially because of the highly 
Bouty, Gomez, \& Godard - Michelin around the world

traditional and conservative local food culture with chefs opposed to any ranking. However and to Michelin's surprise (interview) local authorities proved especially cooperative and even made the most ancient city temple available for the occasion. Additionally, six out of the seven local starred-chefs even attended the event (which meant they accepted not to open their restaurant that night [interview]) and the seventh had his second-chef representing him.

\section{Identical dynamics yet distinct levers}

Comparing the New York and Tokyo dynamics, we acknowledge similar evolutions. The evolution of the total number of press articles dealing with the local red guide is identical with Michelin being a recurrent topic in autumn when the yearly issue is released. The overall evolution of arguments is also similar: the first release was largely debated upon and the vigor of the dispute declined over the years, with arguments becoming in general more favorable to Michelin. Rapidly, the guidebook was taken as a major reference in articles.

However, we also note differences as to the kind of favorable and unfavorable arguments mobilized. The only similarity between the two cities in fact lies in the growing acknowledgement of the Michelin's method, especially its rigor. However, in New York the anonymousness of Michelins inspectors is most often put forward; this is in fact no surprise given the initial prominence of Zagat and the fact that this guidebook rests on customers' plebiscite. That Michelin's inspectors are professionals who work undercover was a strong differentiating characteristic of the red guide. In Japan on the other hand methodological arguments were more centered on the inspectors' skills and their ability to evaluate a cuisine highly different from occidental traditions.

Another difference resides in how the guide's influence on restaurants is acknowledged. In Tokyo, the press echoes business-related effects with an increase in turnover and the number of diners, especially in a difficult economic context. In New York, the acknowledgement of the guide's importance by the chefs is more pregnant as they regularly put forward the legitimacy that its grants them with. Once again, the fact that the Zagat pre-existed in New York can explain this difference: the economic benefits of having the restaurants listed in a guidebook was already a reality in the United States whereas it was more novel in Japan. In addition, the New York culinary scene was already more influenced by the European tradition, with renowned European chefs practicing in the city or American local chefs having apprenticed at starred-restaurants in Europe. Chefs therefore already acknowledged Michelin as an important actor of the gastronomic world. On the contrary in Japan many chefs did not even know the name of the Michelin guide. Their clients on the other hand certainly were more accustomed to the red guide's rakings, especially wealthy clients who used it when travelling in Europe (or lately in New-York). Besides, in Tokyo there is no apparent confusion between starred- and luxury restaurants, 
Bouty, Gomez, \& Godard - Michelin around the world

thus indicating that clients clearly understood the difference. Altogether we record that the levers of Michelin's growing influence have been different in the two cities.

Moe generally, our data also enables us to conjecture over interactions between countries and cities. The New York guide already existed when the first Tokyo edition was issued and it contributed to forming the guide's international status that was early recorded in Japan. This, we analyze, contributed to Michelin easier acceptance in Tokyo. Similarly, the initial existence of a local red guide made the expansion to additional cities (Chicago and Kyoto for that matter) smoother. However our data does not enable us to properly investigate this line of argument and further research could better highlight these synergistic effects in expansion.

Last but not least given our research question, we record that in both New York and Tokyo, the underlying assumptions that base Michelin ranking system are blatantly absent from debates. Articles report on disputes over the method (inspectors, their anonymousness, training or origins...), the guide's prominence (local and international), or its effects (economic and professional) yet never touch on the ranking system itself nor on its logic. The inclusion/ exclusion rule, the stars, the hierarchy, and the international comparison that they make possible are barely discussed. Even less referred to is the underlying cognitive frame granting primary importance to products, cooking's regularity, technical mastery and the chef's creativity. These aspects are not raised as topics and articles only report on chefs being proud or wounded by the ranking. Yet the ranking tools and their underlying assumptions are precisely at the heart of the institutional arrangement carried by the red guide. As Karpik insists they represent a specific and "methodic construction of qualities [author's translation]" (Karpik, 2000: 388) on the base of cultural bourgeois standards initiated during the French revolution and translated into judgment devices (Karpik, 2000) today brought at an international level. Any restaurant rated by Michelin is rated according to these specific gastronomic standards. Acknowledging Michelin (and therefore its ratings) implies acknowledging its underlying system of rules, beliefs, and cultural norms; rules, beliefs, and cultural norms that are de facto placed upon chefs, restaurants, and gastronomic scenes through ratings. In addition and as Karpik (2010) also points out, Michelin, as any other guidebook, is directed to the attention of both consumers (clients) and producers (restaurants and their chefs). As such, the progressive settling down of the red guide in New York and Tokyo reflects that of gastronomy as a set of specific rules progressively accepted by all field constituents, from chefs and restaurants to clients and journalists. That these rules were not discussed and not even hinted at evidences their acceptance, and with it, the successful maintenance of the institutional arrangement they represent. 
Bouty, Gomez, \& Godard - Michelin around the world

\section{DISCUSSION}

Our study contributes to advancing understanding of institutional maintenance work under different aspects, which we discus hereafter: how different forms of maintenance work operate in combination, the tension between geographical expansion and maintenance work, the specific importance of non-peered-based legitimating organizations, and the notion of field in regard of international businesses.

In the first place, our study of the Michelin red guide internationalization to New York and Tokyo points to four types of maintenance work in connection: enabling, policing, valorizing and embedding. By expanding its geographical scope (new countries or cities) Michelin carried out a form of enabling work similar to that of such organizations as the AASCB described in former literature (Durand \& McGuire, 2005; Quinn-Trank \& Washington, 2009 for example): it enabled new constituents to belong to the field as defined by Michelin's standards. Michelin being a legitimating organization with a specific ranking system was also able to perform important policing work in relation, as early as in its initial release in the two cities. This policing work specifically took two forms: rewarding and sanctioning. Michelin rewarded some restaurants and chefs with stars: new starred restaurants in both countries became part of an elite club already existing in Europe as opposed to only belonging to a new local category. Rewarding bore significant consequences over the short term: professional legitimacy for chefs who were familiar with the red guide (especially the case in New York) and revenue (mostly in Japan). This induced prompt initial adherence to the Michelin rules from these actors, a phenomenon of highest importance for institutional maintenance (Quinn-Trank \& Washington 2009: 239). In conjunction, Michelin systematically sanctioned (most often with a lower star ranking) certain restaurants previously acknowledged as prestigious on the local dining scenes: Michelin ignored restaurants celebrated by the Zagat in New-York or was judged unfair in Tokyo for example. Michelin also performed valorizing work: it included (or event granted with stars) restaurants that were considered minor or were less regarded: some restaurants in the Brooklyn district for example, or a restaurant in Tokyo located in a basement, sharing a toilet with other restaurants and that did not even accept credit cards. This later example is of particular importance here as it is highly illustrative of how Michelin worked towards valuing and illustrating the norms it vehicles through the making of positive demonstrative examples. The restaurants at stake were openly celebrated by Michelin (sometimes with stars) for the food they proposed in consistence with the red guide's tradition that food and comfort are two different dimensions (Karpik, 2000). Last, Michelin performed embedding work: the annual release of the guide and the fact that it is regularly saluted in the press echoes the importance of rituals already outlined by Dacin and colleagues (2010). Because of its recurrence the release becomes a routine. Each autumn chefs, restaurants and journalists 
Bouty, Gomez, \& Godard - Michelin around the world

anticipate the new issue of the red guide and grow over the years from debating it to acknowledging and describing the new raking: autumn is a recall. Would the guide be issued more sporadically (for example every two or three years) or erratically (for example at one or another season each year) the effect would certainly be different. Its annual and seasonal regularity creates a rhythm infusing constituents' practices with its mere existence. However, annual releasing consists in embedding work under another important aspect: it implies that a position should never be regarded as definite. More specifically, it combines with enabling, policing and valorizing works to place a permanent tension on chefs who grow eager to either defend or increase their ranking in the next release. That a new edition of the red guide is published each autumn drives chefs to cultivate both hopes (to be included or better rated) and fears (to be excluded or downgraded). These hopes and fears are all the more sensible as Michelin yearly demonstrates that they are justified: Michelin does sanction and reward each year. As such it powerfully infuses restaurants and chefs with Michelin's underlying understanding of gastronomy and deeply contributes to preserving, and reproducing the institutional arrangements that the red guide vehicles. Under this aspect our study points to interrelationships between several types of maintenance work and mutual reinforcement effects. Further research is yet needed to explore these relationships in more details.

In the second place, our results come somehow in contradiction with past studies on maintenance work performed by legitimating organizations. We actually record no change in the red guide's rating system in relation to Michelin's geographical expansion, contrary to what previous studies have put forward. Analysis of the case of the AACSB in particular pointed that maintenance work by this organization involved expansion in combination with the evolution of the accreditation rules in order to respond to new constituent's expectations; the rules, Quinn-Trank \& Washington (2009) showed, evolved towards a mission-based accreditation model as a consequence of the expansion and in return the expansion was also made possible because accreditation rules were transformed. In sharp contrast, our study does not point to such evolution: despite severe attacks, Michelin's rating rules, criteria and overall system did not change as the red guide expanded its geographical scope. Some of Michelin's practices did slightly evolve to better accommodate local circumstances: the inclusion of pictures in Tokyo or of longer texts in New-York. These are evolutions from the initial form of the red guide, which, in Europe, has traditionally been rather austere. However these changes were quite superficial evolutions mainly engaged to gain customer's acceptance through easier use of the guide. They left the underlying framework unchanged. This strategy echoes Zeitsman and Lawrence (2010) argument that boundary and practice work act in combination in institutional processes. However we further point at practice evolutions being potentially loose, especially because our case exemplifies that some 
Bouty, Gomez, \& Godard - Michelin around the world

fundamental cognitive and symbolic rules underlying institutional arrangements can efficiently be maintained as boundaries change. This stability proved even central to Michelin's maintenance work as it directly based policing work, especially rewarding. Michelin stars or the mere inclusion in the guide were rewards precisely because of the Michelin's system stability that made comparison between restaurants possible across the world. It guaranteed that being rewarded in New York, Tokyo, or in Europe was a sign of comparable gastronomic excellence. Therefore newly awarded chefs and restaurants found themselves at the same level than their European (and afterwards New-Yorker) counterparts. Over the years, the stability of the Michelin system was also important for the embedding work of the guide; the significance of changes in restaurants' ratings (therefore positions) is based on the rating rules' stability. Overall that Michelin's underlying rules and norms did not vary was fundamental for the success of the red guide's institutional maintenance through geographical expansion. It significantly contributed to maintaining both Michelin's position and the institutional (especially cognitive) arrangements that the red guide vehicles. Additional research would however be required to complement our results and further analyze the effects of Michelin's expansion over the field in such conditions of unchanged rating rules and norms. In particular and following Zeitsma and Lawrence (2010) argument that practice and boundary work in combination, if Michelin's practices remained stable, it is expectable that others' practices did or will evolve in the future to accommodate new institutional conditions. For example, being regularly rated by Michelin will certainly generate changes in the restaurants practices in New York and Tokyo, with attention growingly granted to the dimensions valued by the red guide. The retro effects of Michelin's expansion on initial field constituents in Europe is also to be investigated: with the comparison being made possible internationally, these starred European restaurants have de facto been placed in a situation of worldwide competition. Last Michelin's practices may also evolve throughout time, especially if the red guide international strategy is pursued with the inclusion of additional cities and countries.

In the third place, our results draw attention toward the specificities of non-peer-based legitimating organizations, their strategy and institutional impact. These organizations play competitive games in which their development and survival impacts institutional considerations. Michelin's dominance is a strategic stake: as the gastronomic world grows international and the guidebooks' content is local, it has to expand its geographical scope to survive competition, attract new customers and generate revenue. Confining its activity to Europe bears the risk of being challenged by other guides (such as the Zagat) and would in the end jeopardize its business on its initial European territory. At the same time, Michelin's indispensable internationalization is coupled with the necessary maintenance of the institutional principles the red guide vehicles. Would fundamental evolutions happen to the 
Bouty, Gomez, \& Godard - Michelin around the world

Michelin system, they would be an acknowledgement of this system becoming non-pertinent and of others being potentially more relevant. From a strategic perspective, this would represent opportunities for competitive guidebooks to gain importance, which is precisely the opposite of Michelin's goal. As such, Michelin's strategy requires that the institutional arrangements that accompanied its development in the past remain in place and it strongly shaped its institutional work. Such perspective on legitimating agencies and their institutional impact is relatively new to our knowledge and very few institutional studies investigated this line of research so far. Recent research has followed quite similar lines of enquiry in the financial sector (Carollilo and colleagues, 2011; White, 2010) to investigate the role of credit rating agencies and other "big players" in the recent financial crisis. Carollilo et al. (2011) especially drew attention towards the "key role [played by] the institutional entrepreneurs [...] in spreading the myth related to the endless market-housing and financial-growth, because it was useful for their aims" (2011: 19). They argue that in an institutional perspective "the key financial players often found their interests aligning with the authorities' philosophy and objectives [...]. When this was not the case, the institutional entrepreneurs exercise all their power, in terms of strategic use of information asymmetries, lobbying, diffusion of rational myths, in order to orient the negotiation tables with the regulators in their favor" (2011: 30). These results, together with ours, open new perspectives on the particular role of non-peered-based legitimating agencies and the institutional impact of their strategies in the contemporary world. Our results also complement Déjean et al. (2004) who showed how an institutional entrepreneur used the development of measurement tools as a strategy to develop its own legitimacy and power, in the context of an emerging business, through a progressive and consensual approach. Further research along this line of enquiry is indisputably necessary given the growing importance of such organizations in an increasing number of fields, from the financial to the education of health sectors. In this perspective, our study sheds also specific light on the power of measuring tools and how it is used by legitimating agencies.

Another insightful perspective would consist in studying the Michelin rating system as a measuring tool, and the cognitive frame it vehicles. Espeland and Stevens (1998) put forward that commensuration was a mode of power, and Espeland and Sauder (2007) further showed that people change their behavior when they are evaluated and their performance measured. Further research could investigate how restaurants reacted to the arrival and development of Michelin ranking system.

\section{CONCLUSION}

How does a dominant non-peer-based legitimating organization work towards institutional maintenance to secure its position in a field? We investigated this question 
Bouty, Gomez, \& Godard - Michelin around the world

based on the case of the Michelin red guide in gastronomical haute cuisine and its internationalization strategy. The famous restaurant guide, which originated in France in the 1920's and spread in Europe over the 20th century, grew outside Europe with the release of the first New York in 2005, and the first Tokyo edition in 2007. We have analyzed this internationalization as institutional work performed by Michelin in order to maintain the field level arrangements that ensured its dominance over gastronomy. We have showed that in both cities, Michelin followed similar trajectories, and combined various types of institutional work in geographic expansion, especially policing, valorizing and embedding that at the same time as it further assed its dominant position. Our research contributes to advancing the understanding of maintenance work, and in particular exemplifies that preserving a dominant position implies actively working towards imposing the symbolic and cognitive systems of rules. We show that field expansion does not necessarily imply the adaptation of rules. Last, we highlight how a non-peer legitimating organization's strategy may impact the field.

\section{REFERENCES}

Carolillo, G., Mastroberardino, M., \& Nigro, C. The 2007 financial crisis: strategic actors and processes of construction of a concrete system. Journal of Management and Gouvernance, Published online first 19 July 2011.

Czarniawska, B. 1997. Emerging institutions: Pyramids or anthills? Organization Studies, 30(4): 423- 441.

Dacin, T. M., Munir, K. \& Tracey, P. 2010. Formal dining at Cambridge colleges: Linking ritual performance and institutional maintenance. Academy of Management Journal, 53(6): 1393-1418.

Daily Yomiuri. 2007. Michelin guide Tokyo to be published in nov. March $19^{\text {th }}$.

Daily Yomiuri. 2007. Michelin stars stir controversy / some Japanese critics question validity of ranking system. November $23^{\text {rd }}$.

Daily Yomiuri. 2009. Is Tokyo really world's No. 1 gourmet city? November $28^{\text {th }}$.

Déjean, F., Gond, J-P., \& Leca, B. 2004. Measuring the unmeasured: An institutional entrepreneur strategy in an emerging industry. Human Relations, 57(6): 741-764.

Durand, R. \& McGuire, J. 2005. Legitimating agencies in the face of selection: The case of AACSB. Organization Studies, 26(2): 165-196.

Espeland, W. N. \& Sauder, M. 2007. Rankings and reactivity: How public measures recreate social worlds. American Journal of Sociology, 113(1): 1-40.

Espeland, W. N., \& Stevens, M. L. 1998. Commensuration as a social process. Annual Review of Sociology, 24: 313-343.

Fauchart, E., \& Von Hippel, E. 2008. Norm-based intellectual property systems: The case of 
Bouty, Gomez, \& Godard - Michelin around the world

French chefs. Organization Science, 19(2): 187-201.

Gomez, M-L, \& Bouty, I. 2011. The emergence of an influential practice: food for thought. Organization Studies, 32(7) 921-940.

Greenwood, R., Suddaby, R., \& Hinings, C. R. 2002. Theorizing change: The role of professional associations in the transformation of institutional fields. Academy of Management Journal, 45(1): 58-80.

Guler, I., Guillén, M. F. \& Macpherson, J. M. 2002. Global competition, institutions, and the diffusion of organizational practices: The international spread of ISO 9000 quality certificates. Administrative Science Quarterly, 47: 207-232.

Hoffman, A. Institutional evolution and change: environmentalism and the US chemical industry. Academy of Management Journal, 42(4): 351-371.

Huault, I. \& Raynelli-Weiss, I. 2011. A market for weather risk? Conflicting metrics, attempts at compromise, and limits to commensuration. Organization Studies, 32(1): 1395-1420.

Jeacle, I., \& Carter, C. 2011. In TripAdvisor we trust: Rankings, calculative regimes and abstract systems. Accounting, Organizations and Society forthcoming 2011, doi:10.1016/j.aos.2011.04.002.

Karpik, L. 2000. Le guide rouge Michelin. Sociologie du Travail, 42(3): 369-389.

Karpik, L. 2010. Valuing the unique: The economics of singularities. Princeton University.

Lane C., 2010. The Michelin-starred restaurant sector as a cultural industry: A cross-national comparison of restaurants in the UK and Germany. Food, Culture and Society, 13(4): 493-519

Lawrence, T. B., \& Suddaby, R. 2006. Institutions and institutional work. In S. R. Clegg, C. Hardy, T. B. Lawrences, \& W. R. North (Eds) Handbook of organization studies $\left(2^{\text {nd }}\right.$ ed.), 215-254. London: Sage.

Lawrence, T. B., Suddaby, R., \& Leca, B. 2009. Institutional work: Actors and agency in institutional studies of organization. Cambridge: Cambridge University Press.

Lawrence, T. B., Suddaby, R., \& Leca, B. 2011. Institutional work: Refocusing institutional studies of organization. Journal of Management Inquiry, 20(1): 52-58.

Lounsbury, M., and \& Rao, H. 2004. Sources of durability and change in market classifications: A study of the reconstitution of product categories in the American mutual fund industry, 1944-1985. Social Forces, 82(3): 969-999.

New York Daily News. 2005. A chef's surprise! Bistro owner stunned to be Michelin man. November $3^{\text {rd }}$.

New York Daily News. 2005. Food (guide) fight. It's Michelin vs. Zagat. November $2^{\text {nd }}$.

New York Daily News. 2005. It's um, um good for boro. 2 eateries touted in Michelin guide. November $4^{\text {th }}$.

New York Daily News. 2005. Michelin rates the apple. September $28^{\text {th }}$. 
Bouty, Gomez, \& Godard - Michelin around the world

New York Daily News. 2007. Ramsay rules bad boy tv chef gets last laugh. October $9^{\text {th }}$.

New York Daily News. 2008. You'll get bang for your bucks at these delish spots. October $7^{\text {th }}$.

Nikkei report. 2007. Michelin guides director says high tokyo ratings justified. December $15^{\text {th }}$. Nikkei Report. 2008. Michelin spurs restaurant-guide boom in Tokyo. November $14^{\text {th }}$.

Nikkei Weekly. 2008. Updated restaurant listing to test whether novelty has faded. November $17^{\text {th }}$.

Ory, P. 1998. Le discours gastronomique français des origines à nos jours. Paris : Gallimard. Parkhurst-Ferguson P.1998. A cultural field in the making: gastronomy in 19th century France. American Journal of Sociology, 104(3): 597-641.

Parkhust-Ferguson, P. 2004. Accounting for taste: The triumph of French cuisine. Chicago: University of Chicago Press.

Parkhust-Ferguson P. 2008. Michelin in America. Gastronomica, 8(1): 49-55.

Phillips N., \& Tracey, P. 2009 Dialogue; Institutional theory and the MNC. Academy of Management Review, 34(1): 169-173.

Quinn-Trank, C., \& Washington, M. 2009. Maintaining an institution in a contested organizational field: the work of the AACSB and its constituents. In T. B. Lawrence, R. Suddaby \& B. Leca (Eds) Institutional work: Actors and agency in institutional studies of organization: 236-261. Cambridge: Cambridge University Press.

Rao, H., Monin, P., \& Durand, R., 2003. Institutional change in toque ville: Nouvelle cuisine as an identity movement in French gastronomy. American Journal of Sociology, 108(4): 795-843.

Ruef, M., \& Patterson, K. 2009. Credit and classification: The impact of industry boundaries in nineteenth-century America. Administrative Science Quarterly, 54: 486-520.

Scott, R. 1991. Unpacking institutional arguments. In W Powell and P. DiMaggio (Eds.), The new institutionalism in organizational analysis: 164-182. Chicago: Chicago University Press.

Scott, R. 2001. Institutions and organizations ( $2^{\text {nd }}$ ed.). Thousand Oaks: Sage.

Svejenova S., Mazza C., \& Planellas, M. 2007. Cooking up change in haute cuisine: Ferran Adrià as an institutional entrepreneur. Journal of Organizational Behavior, 28(5): 539561.

The Japan Times. 2007. Stars in their guides. December $16^{\text {th }}$.

The Japan Times. 2007. Stars in their guides. December $16^{\text {th }}$.

The New York Times. 2005. Is New York worth a trip? Oui. November $2^{\text {nd }}$.

The New York Times. 2005. She's a belle of the city, but the french are blasé. November $13^{\text {th }}$.

The New York Times. 2005. The red (white and blue) guide. March $4^{\text {th }}$. 
Bouty, Gomez, \& Godard - Michelin around the world

The New York Times. 2010. A big man with plenty to say. October $6^{\text {th }}$.

The New York Times. 2010. A hurried announcement for a new Michelin city. November $17^{\text {th }}$.

The Wall Street Journal. 2008. Interview: Michelin Guide eyes more variety in Japan. November $30^{\text {th }}$.

The Wall Street Journal. 2009. Dna 'barcodes' surface fishy imposters on menus; researchers use gene segments to settle restaurant mysteries, check stream quality and take inventory of all living things. December $4^{\text {th }}$.

The Wall Street Journal. 2009. What's not cooking; as some luxury restaurants close, others cut prices; three-course dinners for $\$ 20$. January $23^{\text {rd }}$.

Townley, B. The role of competing rationalities in institutional change. Academy of Management Journal, 45(1): 163-179.

Wedlin, L. 2010. Going global: Ranking as rhetorical devices to construct an international field of management education. Management Learning, 42(2): 199-218.

White, L. J. 2010. The credit rating agencies. Journal of Economic Perspectives, 24(2): 211226.

Zietsma, C., \& Lawrence, T. B. 2010. Institutional work in the transformation of an organizational field: The interplay of boundary work and practice work. Administrative Science Quarterly, 55: 189-221. 
Bouty, Gomez, \& Godard - Michelin around the world

TABLE 1:

Countries covered by the Michelin red guide in 2000

\begin{tabular}{ll}
\hline Annual issues of dedicated guide & Included in the "Main cities of Europe" guide \\
\hline Belgium & Czech Republic \\
France & Denmark \\
Germany & Finland \\
Great Britain & Greece \\
Ireland & Hungary \\
Italy & Norway \\
Luxemburg & Poland \\
Netherlands & Sweden \\
Portugal & \\
Spain & \\
Switzerland & \\
\hline
\end{tabular}


Bouty, Gomez, \& Godard - Michelin around the world

TABLE 2:

Coding, first order categories and second order themes

\begin{tabular}{|c|c|c|}
\hline First order categories & $\begin{array}{l}\text { Second } \\
\text { order themes }\end{array}$ & $\begin{array}{l}\text { General } \\
\text { themes }\end{array}$ \\
\hline $\begin{array}{l}\text { Red guide mentioned as a reference for gastronomy (in } \\
\text { general or to position the level of a restaurant) }\end{array}$ & \multirow{6}{*}{$\begin{array}{l}\text { Michelin red guide's } \\
\text { status }\end{array}$} & \multirow{19}{*}{$\begin{array}{l}\text { Positions } \\
\text { favorable to } \\
\text { Michelin }\end{array}$} \\
\hline $\begin{array}{l}\text { Bible, ultimate arbiter, reference, must, prestigious guide, } \\
\text { highly respected, the most authoritative restaurant guide }\end{array}$ & & \\
\hline International, evaluates several countries & & \\
\hline Mark of quality cooking, synonymous of gastronomy & & \\
\hline Widely distributed, annual sales of around $1 \mathrm{M}$ copies & & \\
\hline $\begin{array}{l}\text { 100-year old guide, venerable guide, long history, has } \\
\text { done this work for a century }\end{array}$ & & \\
\hline Meaningful to chefs, of importance for chefs & \multirow{4}{*}{$\begin{array}{l}\text { Michelin red guide } \\
\text { in the eye of chefs }\end{array}$} & \\
\hline $\begin{array}{l}\text { Michelin stars as a recognition, acknowledgement of } \\
\text { efforts; pride }\end{array}$ & & \\
\hline $\begin{array}{l}\text { Happiness, being rewarded Michelin stars is fantastic, } \\
\text { indescribable joy }\end{array}$ & & \\
\hline $\begin{array}{l}\text { Benefits of a Michelin ranking: increased number of } \\
\text { clients, extra turnover }\end{array}$ & & \\
\hline $\begin{array}{l}\text { General: the Michelin method/ system is unique, } \\
\text { trustworthy... }\end{array}$ & \multirow{9}{*}{$\begin{array}{l}\text { Michelin's method } \\
\text { quality }\end{array}$} & \\
\hline Anonymous inspectors, undercover & & \\
\hline Competent, skilled, inspectors & & \\
\hline Inspectors are Michelin employees & & \\
\hline Inspectors are locals & & \\
\hline Number of restaurants visited by Michelin & & \\
\hline Number of visits by restaurant selected in the guide & & \\
\hline $\begin{array}{l}\text { Recurrence; the guide is issued annually, restaurants can } \\
\text { gain and loose stars }\end{array}$ & & \\
\hline Guide rates only the food, only about the food & & \\
\hline No credibility, decisions are dubious & \multirow{4}{*}{$\begin{array}{l}\text { Critics to Michelin's } \\
\text { method }\end{array}$} & \multirow{9}{*}{$\begin{array}{l}\text { Positions } \\
\text { unfavorable to } \\
\text { Michelin }\end{array}$} \\
\hline $\begin{array}{l}\text { Inspector's competence questioned, skepticism about } \\
\text { Michelin's ability to understand }\end{array}$ & & \\
\hline National culture of inspectors; European inspectors & & \\
\hline $\begin{array}{l}\text { Michelin favors French inspired cuisine / restaurants; three } \\
\text { of its four top restaurants are French }\end{array}$ & & \\
\hline $\begin{array}{l}\text { Michelin rewards luxury restaurants, Michelin restaurants } \\
\text { are expansive }\end{array}$ & \multirow{3}{*}{$\begin{array}{l}\text { Michelin red guide's } \\
\text { orientation }\end{array}$} & \\
\hline Michelin and other guidebooks ratings do not converge & & \\
\hline $\begin{array}{l}\text { Michelin red guide and Michelin tired; springboard for the } \\
\text { tiremaker }\end{array}$ & & \\
\hline $\begin{array}{l}\text { Pressure on chefs; the mere threat of losing a vaunted } \\
\text { star; the pressure it puts on chefs }\end{array}$ & \multirow{2}{*}{$\begin{array}{l}\text { Downside of the } \\
\text { Michelin stars }\end{array}$} & \\
\hline $\begin{array}{l}\text { Attention for stars instead of customers; chefs chase after } \\
\text { stars }\end{array}$ & & \\
\hline
\end{tabular}


Bouty, Gomez, \& Godard - Michelin around the world

FIGURE 1:

Total number of article in the local press on Michelin red guide New-York

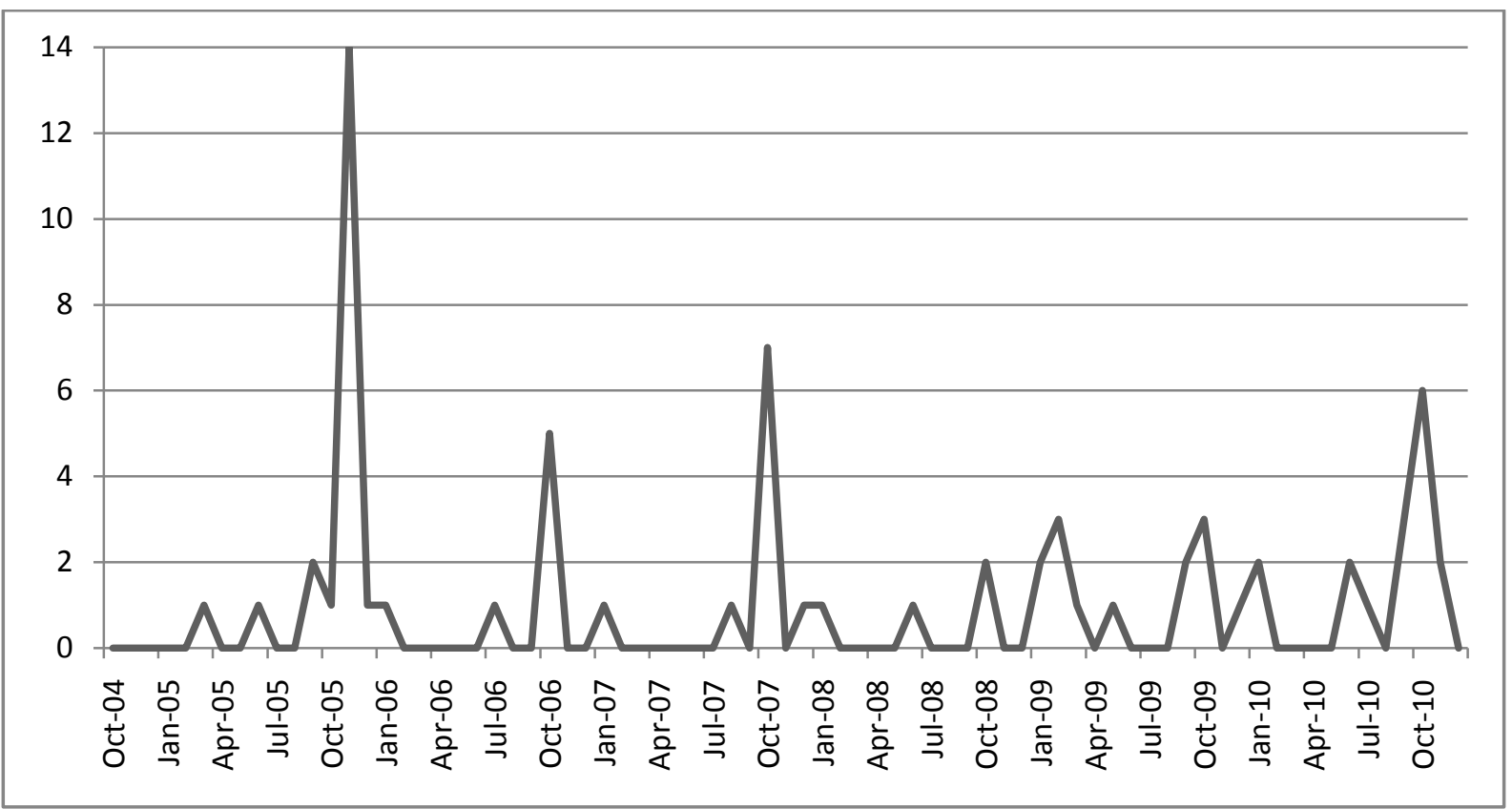

FIGURE 2:

Occurrence of arguments favorable and unfavorable to Michelin in the New York press.

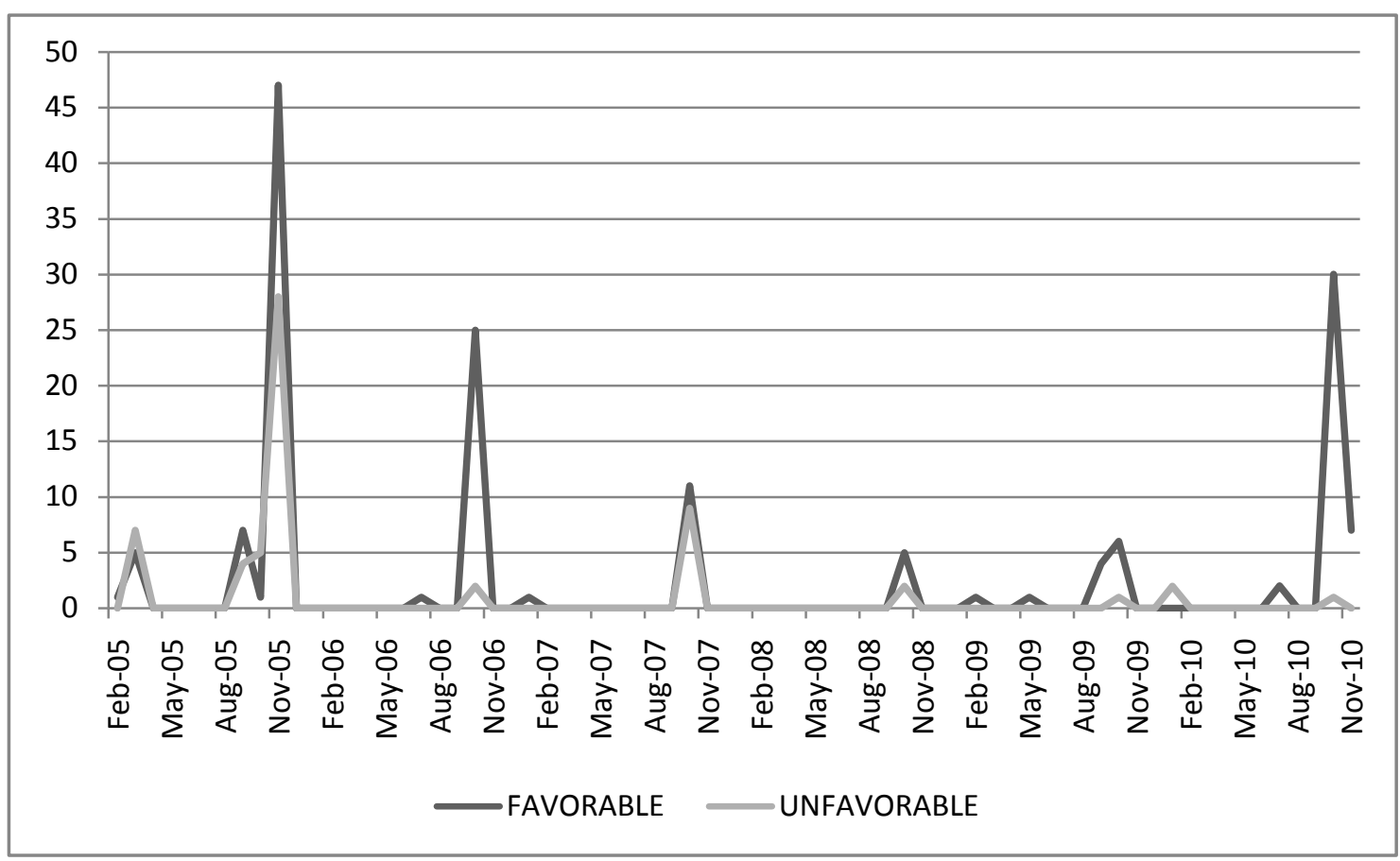


Bouty, Gomez, \& Godard - Michelin around the world

FIGURE 3:

Share of press articles mentioning Michelin as a reference for gastronomy in the New York press

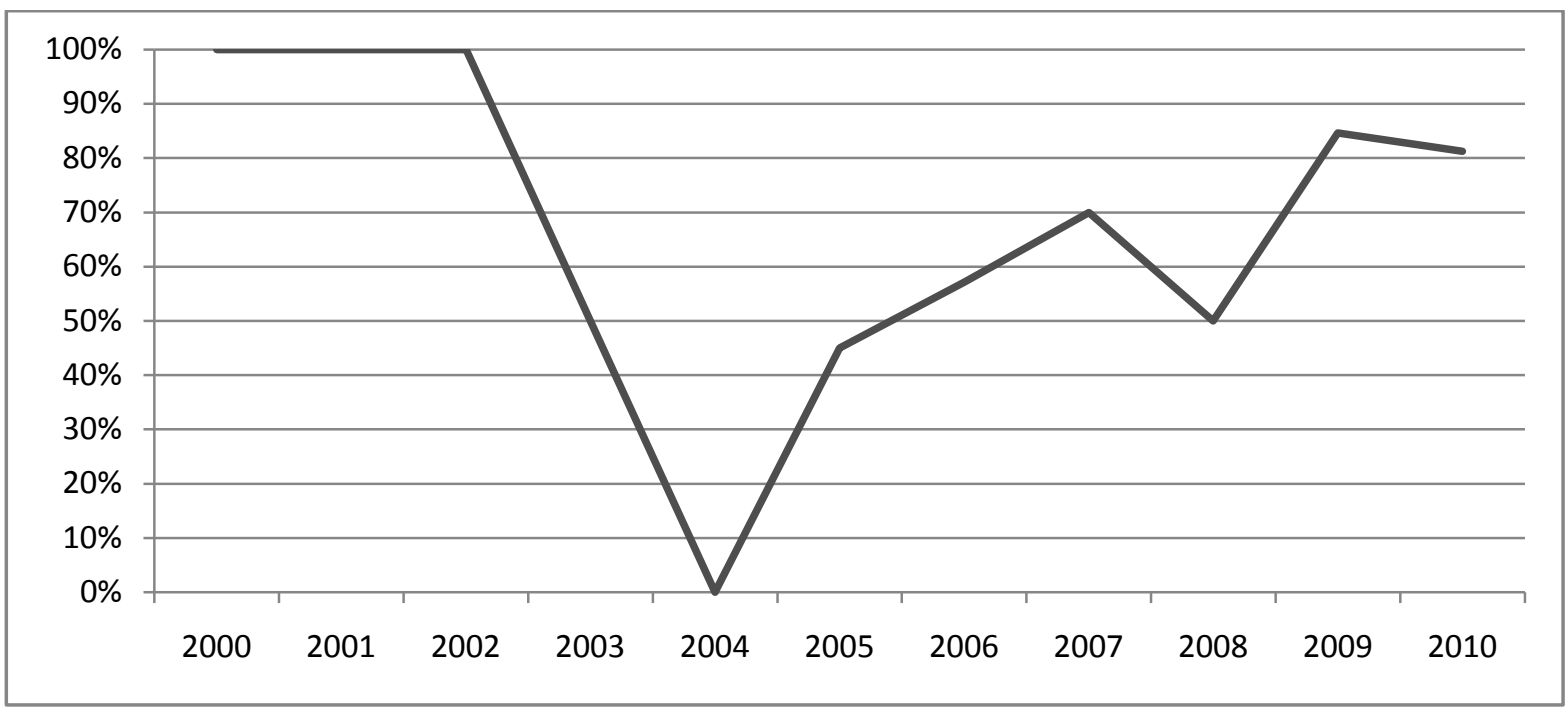

FIGURE 4:

Total number of article in the local press on Michelin red guide Tokyo

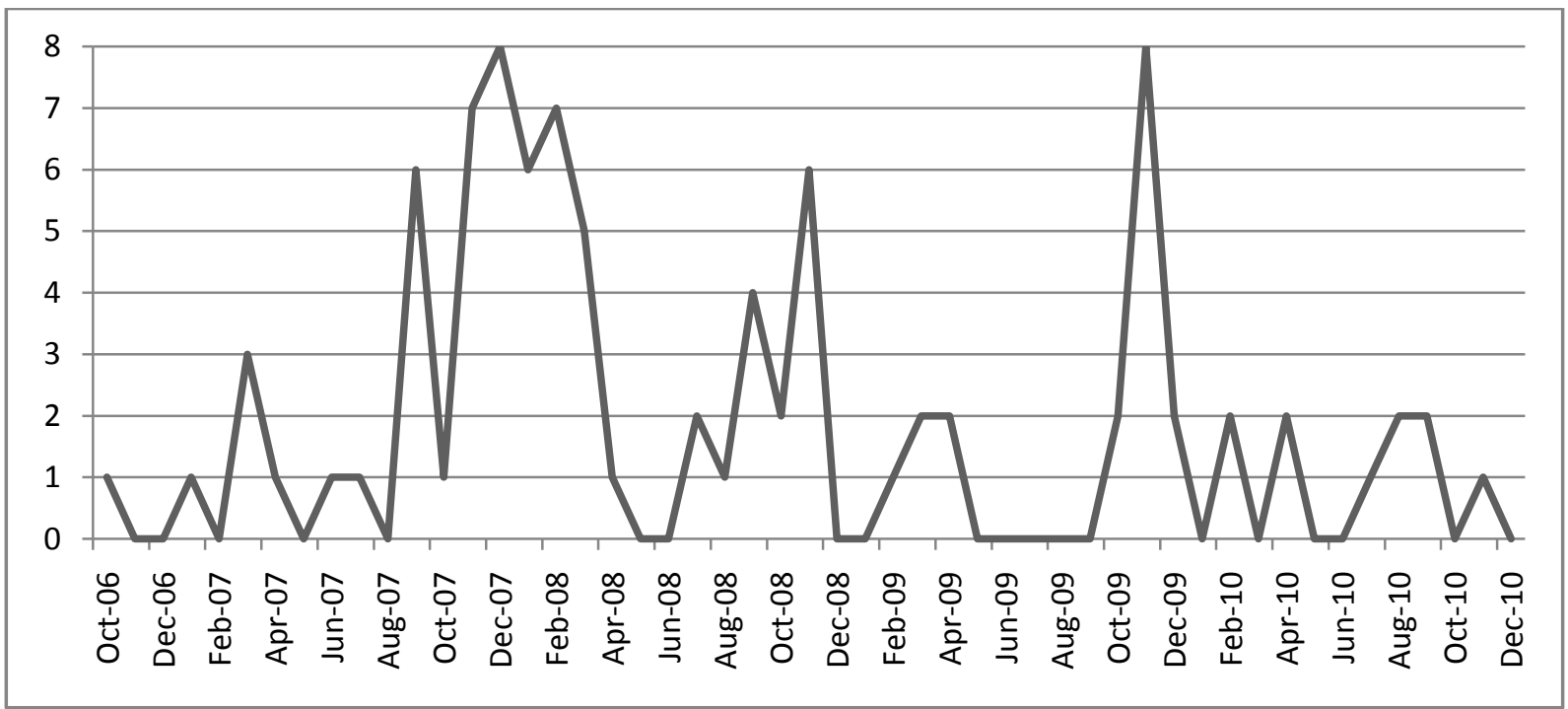


Bouty, Gomez, \& Godard - Michelin around the world

FIGURE 5:

Occurrence of arguments favorable and unfavorable to Michelin in the Tokyo press

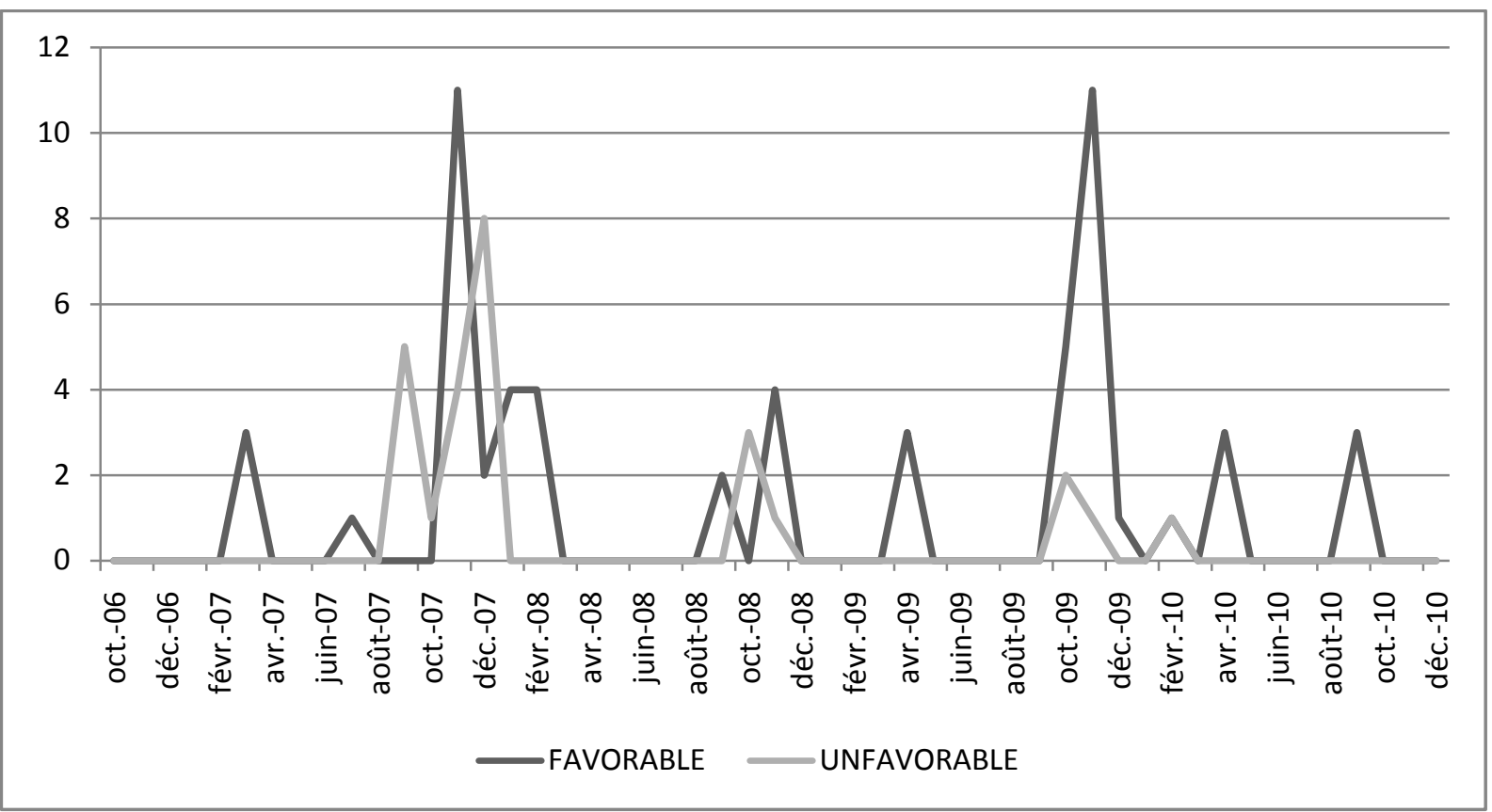

FIGURE 6:

Share of press articles mentioning Michelin as a reference for gastronomy in the Tokyo press

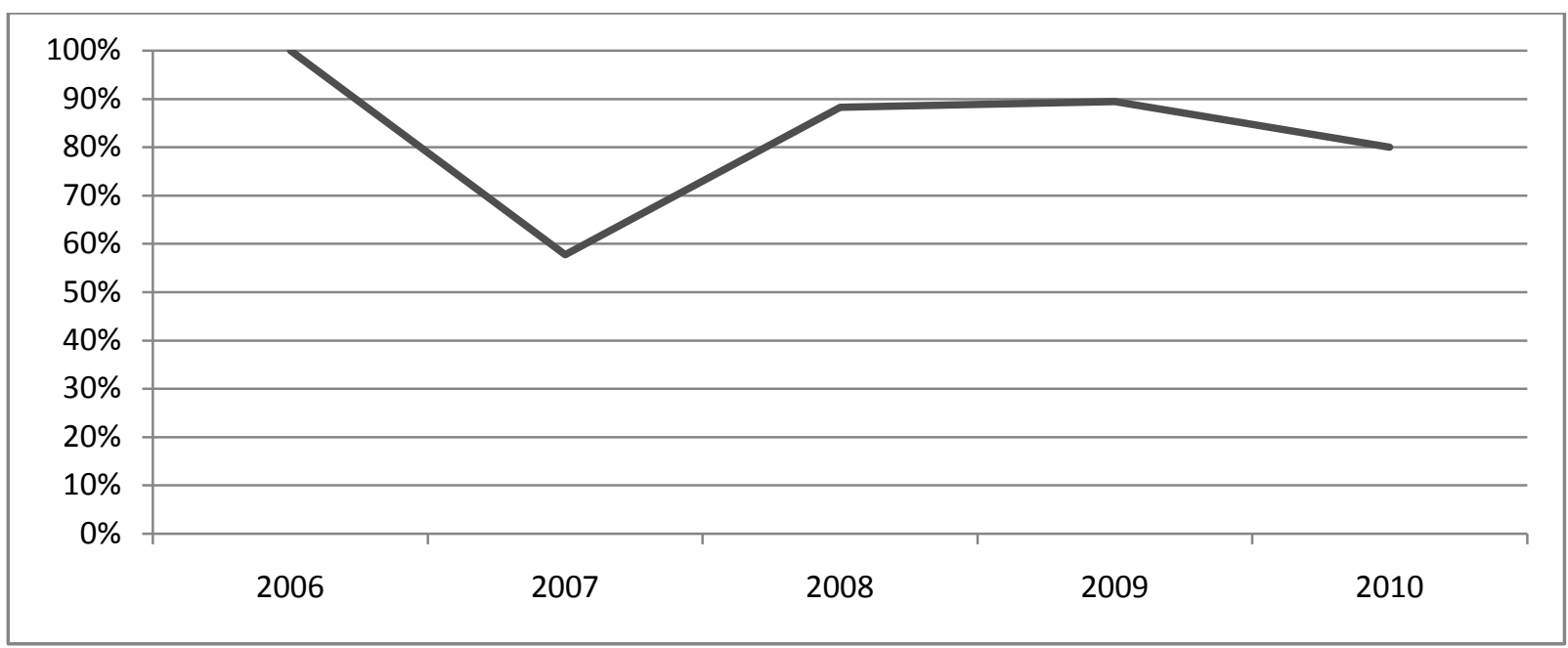


ESSEC Business School Avenue Bernard Hirsch BP 50105

95021 Cergy-Pontoise Cedex

France

Tél. +33(0)134433000

$\mathrm{Fax}+33(0) 134433001$

www.essec.fr

\section{ESSEC Executive Education} CNIT BP 230

92053 Paris-La Défense France

Têl. +33(0)146924900

Fax +33(0)1 46924990

http://formation.essec.fr

ESSEC Business School

Singapore Campus

100 Victoria Street

National Library Building \# 13-02

Singapore 188064

essecasia@essec.fr

Tél. +6568849780

Fax +6568849781

www.essec.edu

Informations

Alison Bougi

+33 (0)134433358

bougi@essec.fr

www.essec.fr

research.center@essec.fr

ISSN 1291-9616 